\title{
COVID-19 and the Transformation of Intimate Inter- and Intra-National Relations
}

\section{Andrew Dawson}

\begin{abstract}
Aвstract: Based conceptually on Michael Herzfeld's ideas of cultural intimacy and disemia, and empirically on lockdown auto-ethnography, this article considers how erstwhile intimate inter-and intra-national relations have been transformed by COVID-19. Its particular ethnographic focus is Australian-British post-colonial relations and the personal emergence of a hybrid Br-Australian consciousness.
\end{abstract}

KeYWords: Australia, Britain, COVID-19, cultural intimacy, disemia, intimacy, national identity

One of the less anticipated impacts of the coronavirus pandemic was how it came to disrupt erstwhile intimate relationships between nations and states. In Australia, where I live, this has been experienced at multiple levels. China is, far and away, Australia's most important trading partner. However, following accusing remarks by the Australian Prime Minister about China's role in the pandemic and racist attacks on Chinese nationals living in Australia (see, for example, Seven News 2020), Australia-China relations have reached a new low. China has engaged in a range of retaliatory measures, including the placing of massive tariffs on some imports and, crucially for the future of the sector in which I work, it has discouraged students from studying in Australia. And, remarkably amidst a crisis in which other forms of investment are so badly needed, the Australian government has recently announced its largest ever investment in defence, principally to guard against potential aggression from China in the South China Sea.

Further down the pecking order, the Australian federation has been strained by two key events. The first of these was profound disagreements between the federal government and Australia's constitutive states about the measures required to manage the pandemic. The most notable amongst these was disagreement about 'containment' or 'eradication' between the more neoliberal federal state, with its emphasis on opening the economy, and the state of Victoria's seemingly predominant emphasis on the saving of lives. This hinted too towards the development of new intimacies, between Victoria and New Zealand, for example, where a policy of eradication has been pursued aggressively. Second, and in a wholly unprecedented event, temporary hard borders have been erected between the constitutive nations of the federation, for the purposes of containment of the virus.

My concern in this article is, however, with another inter- and intra-national level - how a pandemic can transform personal nationalisms (Cohen 1996), the relationship between national identities within oneself. In the manner of so much lockdown anthropology, this is an auto-ethnography (Reed-Danahay 1997), which considers my experience of being an immigrant from the United Kingdom in Australia during the pandemic. I begin by highlighting a peculiarly alienating experience felt by many such immigrants - living with what appears as a profound contradiction in Australian national culture and identity between a celebrated disdain for authority (or 'larrikinism' as I label it) and a concealed over-respect for rules and procedures (or 'bureaucratise' as I label it). My conceptualisation of the tension rests on Michael Herzfeld's (2016) idea of cultural intimacy, 
and, like Herzfeld, I go on to suggest that tensions of this type are especially prevalent in settler-colonial contexts like Australia, where, in this case, the overrespect is an embarrassing trace of cultural forms bequeathed by the colonist. However, and building upon Herzfeld once more, I argue that the pandemic represents a moment of 'disemic resolution' in which the celebrated and the concealed came to elide.

Personally, the coming to consciousness of that elision came through nightly Zoom calls to family and friends in the United Kingdom, when, in the midst of the United Kingdom's horrific COVID-19 crisis, I became increasingly alienated from and enamoured by British and Australian reactions to the pandemic, respectively. Through this experience, and through mundane and shocking utterances where for the first time in my life I caught myself saying things like 'we Australians' (if not quite yet 'you British') I felt a sense of my transitioning to a hybrid status of Br-Australianess. Until then, I had always thought of myself as a 'Brit' abroad. Though based on a highly individual and personal example, reflecting on a process within a profoundly multicultural society, the article might point to broader processes of national transformation taking place within Australia as a consequence of the pandemic, and broader transformations in Australians' post-colonial relations to and intimacies with the United Kingdom.

\section{Behind Every Larrikin Is a Bureaucrat: Australia's Dirty Laundry}

A common experience amongst immigrants (like me) in Australia is how national stereotypes, both negative and positive, are confounded through living here. ${ }^{1}$ The national auto-stereotype of the larrikin is a case in point. The Oxford Modern Australian Dictionary a key arbiter of things Australian in and of itself describes the larrikin as 'a person who acts with apparent disregard for social or political convention' (Ludowyk and Moore 2000). Prior to its being established through the First World War as an archetype of national character, larrikinism's connotations were both negative and positive - from anti-social behaviour through to, crucially (as we will come to see), healthy disdain for authority.

Yet, larrikinism is constantly undermined as a contemporary national auto-stereotype by many Australians' apparently automatic recourse to and easy acceptance of rules and procedures, and their institutional embodiment in the form of the modern bureaucracy. For example, a common post-work story shared amongst international neophytes within the Australian university where I work goes something like this: 'A small but niggly issue cropped-up at work today. I sought advice from my manager. S/he referred me to policy $\mathrm{X}$, clause $\mathrm{Y}$ and sub-clause $\mathrm{Z}$. Unfortunately, I couldn't understand it because of all the acronyms. Mildly surprised by my unfamiliarity, s/he kindly translated them, and the policy in general. However, at the end of it we deduced mutually that the policy did not legislate for or furnish a resolution to the minor issue at hand. S/he concluded that a resolution must come through policy change. It may take a while though because it will have to be transitioned through a number of committee levels. What the fuck! Couldn't we just have cobbled something together on the spot in order to get by?'

Herzfeld offers some insight into confounded national stereotypes. He defines cultural intimacy as 'the recognition of those aspects of a cultural identity that are considered a source of external embarrassment but that nevertheless provide insiders with their assurance of a common sociality' (2016: 3). And so, in relation to national belonging, Herzfeld implies, the essence of a nation and the key means through which its members derive solidarity lies primarily in those aspects of national identity that the nation conceals from others. Furthermore, being a national involves living endlessly with ambivalence and contradiction between what the nation over-represents and what it wants to conceal - respectively larrikinism and bureaucratise in the case of Australia I would suggest.

Furthermore, Herzfeld continues, nowhere is his 'dirty laundry' theory of nationalism more applicable than in settler-colonial societies - namely, places like Australia. Indeed, as historian of Australia Alan Atkinson (2000) suggests, the country was developed by its colonists as a post-Enlightenment project framed by modern forms of bureaucratic rationalisation whose likes were the stuff of impractical dream back in the British 'motherland' with its obdurate traces of non-modern ways. There are, then, deep-seated historical reasons why bureaucratise and its concealing larrikin obverse are both central to the Australian national condition.

\section{Citizenship and Bureacratise}

Building on the ideas of Max Weber, certainly the greatest scholar of modernity, rationalisation and bureaucracy, George Ritzer (2018) shows that when rationalisation and bureaucratise are taken to extremes irrational outcomes ironically eventuate. The 
example I present above may be a case in point - a policy for problem resolution forestalls problem resolution by obviating the possibility of other nonpolicy means of problem resolution that may readily be at hand.

Fittingly for an immigrant such as me, no aspect of Australian bureaucratise has appeared to match the description of the irrationality of rationality better than the official process of becoming Australian itself. Like all rites of passage, citizenship entails the three phases of separation, liminality and aggregation (Van Gennep 1909). The processes of preparing for the citizenship test, sitting the citizenship test and participating in the citizenship ceremony, where one is finally 'aggregated' into the mass of other Australians, correspond. In each case, the levels of apparent bureaucratic absurdity were something to behold.

Some years after arriving from the United Kingdom, and in preparation for the test, I asked a Department of Immigration and Multicultural Affairs and Indigenous Affairs official whether it is indeed the case that the kangaroo is Australia's national animal. In bureaucracy-speak, he warned me that, while it was commonly regarded as so being, its status as such had 'not yet been officially ratified'.

Then, in what seemed to me to be a test of whether one understood what it took to be a citizen of any liberal democratic society rather than Australia in particular, I recall a multiple-choice question going something like this: 'Which of the following is not a legitimate form of protest in Australia: (a) writing to your federal Member of Parliament; (b) signing a petition; (c) engaging in a peaceful demonstration; or (d) throwing a firebomb through the window of the federal Parliament building?'

However, nowhere was such irrationality of rationality more evident to me than in the otherwise very welcoming citizenship ceremony I participated in at my local town hall. It was beset by all the seemingly irrational oxymorons typical of national projects in general. For example, nations are imagined as cultural wholes, but are celebrated with fragmentary cultures (Hobsbawm and Ranger 1992), such as the intrinsically Gypsy and marginal cultural form of flamenco that is so central to Spanishness.

Likewise, they are imagined as ancient when, in fact, the idea of the nation is, largely an invention of nineteenth-century Europeans and their diasporas (Segal and Handler 1992). Indeed, one might argue, there is often a converse relationship between the newness of nation-states and the extent they go to demonstrate their ancientness. A case in point might be investment by the relatively newly independent nation-state of Bosnia and Herzegovina to demonstrate via archaeology the almost certainly nebulous idea that most converts to Islam were once part of the ancient ascetic sect of Bogomils and not Orthodox Christians, as many Serbs would have it (Malcolm 1994).

Finally, and most importantly, while the nation is invariably imagined and celebrated as natural, that is, of course, an artifice. The Australian citizenship ceremony is wonderfully illustrative of this. Towards its ritual climax, we stranger initiates were made to hold hands, sway as one, and garble national songs whose words and meanings were unknown to most of us. None of us knew (does anyone?) the words of the national anthem. So, instead the organisers chose a song called 'I Still Call Australia Home' for the ceremonial climax. Part of a ubiquitous television advertisement for Qantas, the national airline carrier, most of us knew at least some of the words. Consequently, even when I come fully to 'still call Australia home', an association of the nation with air miles rather than with ANZACS ${ }^{2}$ is inevitable. Then finally, a secondstring actor from one of Australia's greatest exports, the television soap opera Neighbours, gifted each of us a native seedling. Despite the artificiality of the entire process, that symbolised the fact that, as she declared, we were now 'naturalised!'

\section{COVID-19 and Becoming Br-Australian}

In the years that passed after becoming an 'official' Australian, 'becoming' Australian in the existential sense of the word eluded me. Only being in the United Kingdom afforded that sense of oneness. The relief when stepping onto the departures terminal concourse at Heathrow Airport was palpable. However, the coronavirus pandemic disrupted all that. And, in the process it made me aware of a transforming of my sense of national identification from British to, perhaps, a hybrid Br-Australianess.

Despite a devastating 'second wave' of infections in my home city of Melbourne through the months of June, July and August 2020, the contrasting COVID-19 (mis-)fortunes of Australia and Britain overall have been stark. Notably, while Australia succeeded in 'flattening the curve' early, the United Kingdom has experienced the worst infection and mortality rates in Europe. And that situation seems to have been concealed. For example, one analysis conducted by the Financial Times in late April put the number of deaths in the United Kingdom at 41,000, rather than the 17,337 portrayed in official statistics (Giles 2020). 
It became clear early on that the UK government's handling of the pandemic came far too late (Walker 2020). It was clearly botched (Toynbee 2020). Perhaps more than good public health sense it seemed to be guided by a large dose of cronyism (Maughan 2020). And, it was tainted by significant ideological zealotry. For example, early shortages of Personal Protective Equipment (PPE) for health-care workers were due in part to a post-Brexit reluctance to collaborate with the European Union (Boffey 2020). Furthermore, of course, these short-term problems were compounded by longer-term underfunding of the National Health Service (NHS), which certainly exacerbated the national mortality rate (Financial Times 2020).

However, besides governmental failure, matters of national identity played a part in my understandings of the contrasting (mis-)fortunes and my emerging sense of Br-Australianess too. Three matters in particular loomed large.

The first of these was British individualism (MacFarlane 1978). Once lauded for great achievements such as the Industrial Revolution, it appeared to manifest during the pandemic in widespread contraventions of guidelines on social distancing (BBC News 2020) as a kind of dangerous hedonism (see also Herzfeld in this Volume). In contrast, save for the occasional conflict over goods in short supply (see Décobert in this issue) collective responsibility has appeared widespread in Australia. And, save for some limited transgressions, adherence to social distancing has appeared to be widespread too. Indeed, as I write, even the recent 'second wave' in Melbourne is, wrongly or rightly, attributed widely as being rooted in the transgressions of one local 'patient zero' in a Quarantine Hotel. In some gossip, and in signs of an emerging negative national stereotype of the colonial motherland, he is alleged to have gotten too intimate with - surprise, surprise - hedonistic, selfish and reckless quarantining British tourists.

Second, in the United Kingdom the pandemic often appears to be presented as a re-run of the Second World War with COVID-19 playing the role of the Nazis and NHS workers playing the role of the British troops (see also McLeod et al. in the previous issue). ${ }^{3}$ The epitome of a sad pact between government and the people in this respect was the weekly national ritual in which citizens and politicians alike came out of their homes to applaud the health-care workers (Mohdin 2020), the nation's heroes at a Dunkirk and Blitz-like moment. This was a heartfelt expression of care and national solidarity no doubt. However, and carrying through the Second
World War comparisons that have been aplenty in the United Kingdom (Tisdall 2020), it appears akin to Germany's pathetic gesture of air dropping medals to its supply-starved soldiers on the Eastern Front. Surely health-care workers need PPEs more than VCs. ${ }^{4}$ Contrastingly, and thankfully, Australians have been spared, and have largely refrained from misuse of the ANZAC legend. Rather, the 'war' on COVID-19 has barely been represented as a war at all. Rather, it is simply a health and social crisis to be understood and responded to through the prisms of science and economics alone.

Third, despite massive and documented failings, the British government has proclaimed its response to the pandemic "a success" (Bloom 2020). The charade has been maintained by numerous nebulous claims, such as the presentation of a badly functioning infection 'track and trace' system as 'worldbeating' and a reluctance to subject the government's approach to independent enquiry. Yet, and in a place that was long regarded as the 'cradle of democracy', for a significant time during the pandemic opinion polls indicated that the British public concurred with the government's positive self-assessment (Curtis 2020). In contrast, Australia's most significant political moment during the pandemic came when both states within the federation and almost certainly the mass of ordinary citizens defied government as it erred on its own social-distancing measures, such as when its openly religious Prime Minister tried to exempt churches from closure over the Easter period.

\section{Conclusion: Disemic Resolutions}

Later on in his development of the cultural intimacy thesis, Herzfeld (2016) describes the condition of 'disemia'. In essence, this is when a nation's external and internal (i.e. concealed) representations of identity and sociality come into tension. What I experienced during the pandemic was, instead, what one might describe as a moment of disemic resolution - between bureaucratise and larrikinism. Here, especially when states and people resisted the Prime Minister's call to open churches, was a moment when larrikinism in the form of healthy disdain for authority was put to work in a public insistence on the implementation of rational rules and procedures. Bureaucratise and larrikinism - concealed and represented became one!

This took place at the very moment when the individualism that as a citizen of the United Kingdom I had been schooled into believing was intrinsic to Britishness appeared to manifest as dangerous he- 
donism. Likewise, it took place at the moment when the reason and democratic ethos that I had also been schooled into believing were intrinsic to Britishness appeared to be undermined by wartime nostalgia and authoritarianism (especially in the form of praise for faux Churchillian leaders [Wheatcroft 2020]). And, at this moment I came to feel a little less British (for a contrasting example, see Michael Ulfstjerne's article in the previous issue) and a little more Br-Australian. Sociologists often tell us that national becoming is a long and slow process of assimilation or acculturation. However, sometimes it comes about suddenly in critical moments. The COVID-19 pandemic is one such moment, when national intimacies - from the geopolitical to the deeply personal - are realigned.

Andrew Dawson is Professor and Chair of Anthropology at the University of Melbourne. He conducts ethnographic research in Australia, Bosnia and Herzegovina, and the United Kingdom, mostly on the broad issue of contemporary mobilities.

E-mail: dawsona@unimelb.edu.au

\section{Notes}

1. This is an extended version of a previously published article that has also been reworked in light of the many instructive comments from readers (Dawson 2020).

2. The Australian and New Zealand Army Corps. Especially because of its role in the Gallipoli Campaign, it is central to Australian national identity.

3. A more disturbingly racist trope sometimes deployed is that of COVID-19 as 'mugger', a term that was used to stereotype Black people in Britain as criminal in the 1970s. Prime Minister Johnson has explicitly used the analogy.

4. Victoria Cross - the highest medal for gallantry that can be awarded to military personnel in Britain and the Commonwealth.

\section{References}

Atkinson, A. (2000), The Europeans in Australia: Volume 1 (Sydney: UNSW Press).

BBC News (2020). 'Coronavirus: "Selfish Minority" Flout Lockdown over Easter', BBC News, 15 April, https://www.bbc.com/news/uk-wales-52299560.

Bloom, D. (2020), 'Boris Johnson Hails 'Apparent Success' against Coronavirus despite 20,000 Deaths', Mirror, 27 April, https://www.mirror.co.uk/news/ politics/boris-johnson-says-apparent-success21932034.

Boffey, D. (2020). 'What Is the EU Medical Equipment Scheme and Why Did the UK Opt Out?' The Guardian, 22 April, https://www.theguardian.com/ world/2020/apr/22/coronavirus-what-is-eu-medicalequipment-scheme-why-did-uk-opt-out.

Cohen, A. P. (1996), 'Personal Nationalism: A Scottish View of Some Rites, Rights, and Wrongs', American Ethnologist 23, no. 4: 802-815, doi:10.1525/ ae.1996.23.4.02a00070.

Curtis, C. (2020), 'COVID-19: Support for Government Reaction Swells', YouGov, 27 March, https://yougov .co.uk/topics/politics/articles-reports/2020/03/27/ covid-19-support-government-reaction-swells.

Dawson, A. (2020), 'How COVID-19 Made Me More Australian', Pursuit 19 June, https://pursuit.unimelb .edu.au/articles/how-covid-19-made-me-moreaustralian.

Financial Times (2020), 'Britain's National Health Service Needs More than Plaudits to Beat COVID-19', Financial Times, 1 April, https://www.ft.com/content/ bd574d3a-7345-11ea-95fe-fcd274e920ca.

Giles, C. (2020), 'UK Coronavirus Deaths More than Double Official Figure, according to FT Statistics', Financial Times, 21 April, https://www.ft.com/ content/67e6a4ee-3d05-43bc-ba03-e239799fa6ab.

Herzfeld, M. (2016), Cultural Intimacy: Social Poetics and the Real Life of States, Societies and Institutions, 2nd ed. (New York: Routledge).

Hobsbawm, E., and T. Ranger (eds) (1992), The Invention of Tradition (Cambridge: Cambridge University Press).

Ludowyk, F., and B. Moore (2000), Oxford Modern Australian Dictionary (Oxford: Oxford University Press).

MacFarlane, A. (1978), The Origins of English Individualism: Family, Property and Social Transition (Oxford: Blackwell).

Malcolm, N. (1994), Bosnia: A Short History (New York: New York University Press).

Maughan, J. (2020), 'COVID-19 Contracts Smell of Cronyism - So I'm Taking the Government to Court', The Guardian, 16 November, https:www .theguardian.com/commentisfree/2020/nov/16/ covid-19-contracts-cronysism-government-courst

Mohdin, A. (2020), 'Pots, Pans, Passion: Britons Clap their Support for NHS Workers Again', The Guardian, 2 April, https://www.theguardian.com/ world/2020/apr/02/pots-pans-passion-britons-claptheir-support-for-nhs-workers-again.

Reed-Danahay, D. (ed.) (1997), Auto/Ethnography: Rewriting the Self and the Social (New York: Berg).

Ritzer, G. (2018), The McDonaldization of Society, 9th ed. (New York: Sage). 
Segal, D. A., and R. Handler (1992), 'How European Is Nationalism?' Social Analysis: The International Journal of Anthropology 32: 1-15, https://www.jstor.org/ stable/23164547.

Seven News (2020), 'Coronavirus: University of Melbourne International Students Assaulted in Unprovoked Racist Attack' Seven News, 17 April, https:// 7news.com.au/lifestyle/health-wellbeing/coronavi rus-university-of-melbourne-international-studentsassaulted-in-unprovoked-racist-attack-c-983675.

Tisdall, S. (2020), 'Lay off Those War Metaphors World Leaders: You Could Be the Next Casualty', The Guardian, 21 March, https://www.theguardian .com/commentisfree/2020/mar/21/donald-trumpboris-johnson-coronavirus.

Toynbee, P. (2020), 'Boris Johnson Is Clearly the Wrong
Man in the Wrong Job at the Wrong Time,' The Guardian, 23 April, https://www.theguardian.com/ world/2020/apr/23/the-costly-mistakes-of-bumb ling-boris-johnson.

Van Gennep, A. (1909), Les Rites de Passage [Rites of passage] (Paris: Émile Nourry).

Walker, P. (2020), 'Tories on Defensive as Criticism Grows of Early Handling of Coronavirus', The Guardian, 19 April, https://www.theguardian.com/ world/2020/apr/19/pm-was-missing-in-action-dur ing-early-phase-of-pandemic-claims-labour.

Wheatcroft, G. (2020), 'Johnson and Churchill? History Really Does Repeat Itself as Farce', The Guardian, 20 March, https://www.theguardian.com/commen tisfree/2020/mar/20/johnson-as-churchill-historyrepeat-as-farce. 